\title{
Performances and microbial features of an aerobic packed-bed biofilm reactor developed to post-treat an olive mill effluent from an anaerobic GAC reactor
}

\author{
Lorenzo Bertin $^{\dagger 1}$, Maria Chiara Colao ${ }^{\dagger 2}$, Maurizio Ruzzi $^{\dagger 2}$, \\ Leonardo Marchetti ${ }^{\dagger 1}$ and Fabio Fava*†1
}

Address: ${ }^{1}$ DICASM, Faculty of Engineering, University of Bologna, viale Risorgimento 2, I-40136 Bologna, Italy and ${ }^{2}$ DABAC, University of Tuscia, Via C. de Lellis, snc. I-01100 Viterbo, Italy

Email: Lorenzo Bertin - lorenzo.bertin@unibo.it; Maria Chiara Colao - colao@unitus.it; Maurizio Ruzzi - ruzzi@unitus.it; Leonardo Marchetti - leonardo.marchetti@unibo.it; Fabio Fava* - fabio.fava@unibo.it

* Corresponding author †Equal contributors

Published: 05 April 2006

Microbial Cell Factories 2006, 5:16 doi:10.1 186/1475-2859-5-16
Received: 07 February 2006

Accepted: 05 April 2006

This article is available from: http://www.microbialcellfactories.com/content/5/1/16

(C) 2006 Bertin et al; licensee BioMed Central Ltd.

This is an Open Access article distributed under the terms of the Creative Commons Attribution License (http://creativecommons.org/licenses/by/2.0), which permits unrestricted use, distribution, and reproduction in any medium, provided the original work is properly cited.

\begin{abstract}
Background: Olive mill wastewater (OMW) is the aqueous effluent of olive oil producing processes. Given its high COD and content of phenols, it has to be decontaminated before being discharged. Anaerobic digestion is one of the most promising treatment process for such an effluent, as it combines high decontamination efficiency with methane production. The large scale anaerobic digestion of OMWs is normally conducted in dispersed-growth reactors, where however are generally achieved unsatisfactory COD removal and methane production yields. The possibility of intensifying the performance of the process using a packed bed biofilm reactor, as anaerobic treatment alternative, was demonstrated. Even in this case, however, a post-treatment step is required to further reduce the COD. In this work, a biological post-treatment, consisting of an aerobic biological "Manville" silica bead-packed bed aerobic reactor, was developed, tested for its ability to complete COD removal from the anaerobic digestion effluents, and characterized biologically through molecular tools.

Results: The aerobic post-treatment was assessed through a 2 month-continuous feeding with the digested effluent at 50.42 and $2.04 \mathrm{gl}^{-1} \mathrm{day}^{-1}$ of COD and phenol loading rates, respectively. It was found to be a stable process, able to remove 24 and $39 \%$ of such organic loads, respectively, and to account for I/ 4 of the overall decontamination efficiency displayed by the anaerobic-aerobic integrated system when fed with an amended OMW at 31.74 and $1.70 \mathrm{~g}^{-1}$ day $y^{-1}$ of COD and phenol loading rates, respectively. Analysis of $16 \mathrm{~S}$ rRNA gene sequences of biomass samples from the aerobic reactor biofilm revealed that it was colonized by Rhodobacterales, Bacteroidales, Pseudomonadales, Enterobacteriales, Rhodocyclales and genera incertae sedis TM7. Some taxons occurring in the influent were not detected in the biofilm, whereas others, such as Paracoccus, Pseudomonas, Acinetobacter and Enterobacter, enriched significantly in the biofilter throughout the treatment.

Conclusion: The silica-bead packed bed biofilm reactor developed and characterized in this study was able to significantly decontaminate anaerobically digested OMWs. Therefore, the application of an integrated anaerobic-aerobic process resulted in an improved system for valorization and decontamination of OMWs.
\end{abstract}




\section{Background}

Olive mill wastewater (OMW) is the effluent resulting from olive oil producing processes. Due to their high COD loading rates and content of toxic phenolic compounds, OMWs have to be decontaminated before being discharged $[1,2]$. Among the treatment methods currently available for this effluent, anaerobic digestion is generally considered the most promising because of its ability to combine a marked OMW decontamination potential with the ability to generate biogas rich of $\mathrm{CH}_{4}[3,4]$. The large scale anaerobic digestion of OMWs is normally conducted in dispersed-growth reactors, where however the removal of the toxic phenolic fraction is often unsatisfactory $[5,6]$. The possibility of intensifying the dephenolisation potential of the process by performing it in anaerobic column reactor packed with granular activated carbon (GAC) was recently demonstrated $[7,8]$. GAC-digestor resulted to be a reproducible and stable OMW digesting process capable of a tolerance to high OMW organic loads and methanogenic performances significantly higher than those of the other bench-scale up-flow packed-bed biofilm OMW digestors described so far in the literature [3,9-11] and of those of the dispersed-growth digestors previously developed with the same microbial inoculum $[7,12,13]$. Molec- ular analysis of GAC-packed bed biofilm showed that it was heterogeneously composed by a large number of Proteobacteria, bacteria of the Flexibacter-Cytophaga-Bacteroides group, sulfate-reducing bacteria and low $\mathrm{G}+\mathrm{C}$ gram-positive bacteria along with a limited number of highly abundant Archaea taxons mostly due to Methanobacterium formicicum [8].

Despite of its improved OMW decontamination performances, GAC-digestor generated effluents with a COD generally too high to allow their release in the environment or their use in agriculture [14]. Thus, the opportunity to implement the GAC-digestor decontamination potential by integrating it with an aerobic biological post-treatment was explored in this study. A "Manville" silica bead (SB)packed bed aerobic reactor was developed, hydraulically connected to the GAC-digestor and employed to posttreat OMW digested effluents. The integrated anaerobicaerobic process was operated in continuous mode and assessed through a 2 month experiment. In this paper the decontamination potential and main microbial features (e.g., structure and spatial distribution of reactor microbial community) of the aerobic post-treatment are reported and discussed. Despite the large number of stud-

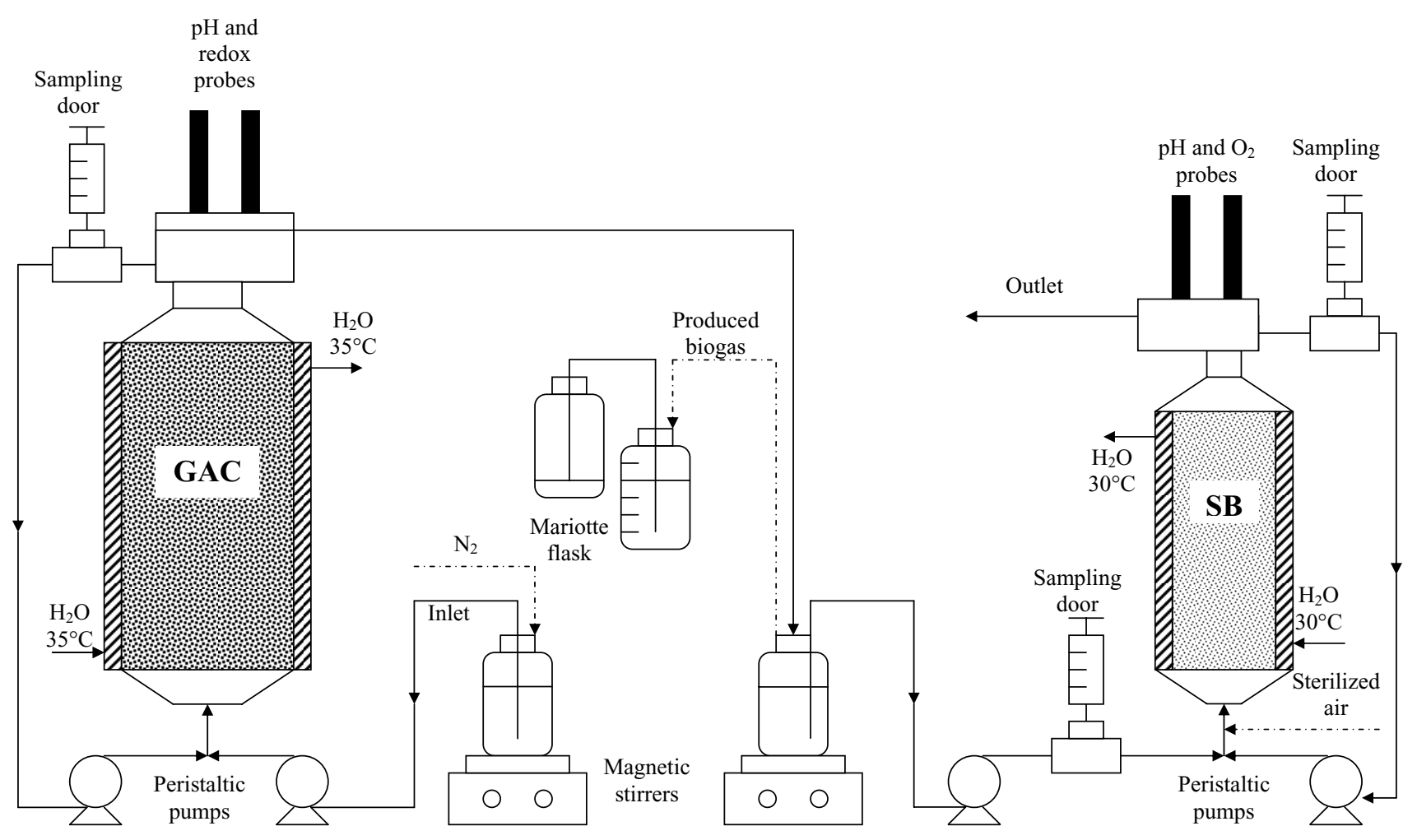

Figure I

Integrated anaerobic-aerobic biofilter system. Scheme of the anaerobic-aerobic packed bed reactor system developed in the study. 
a

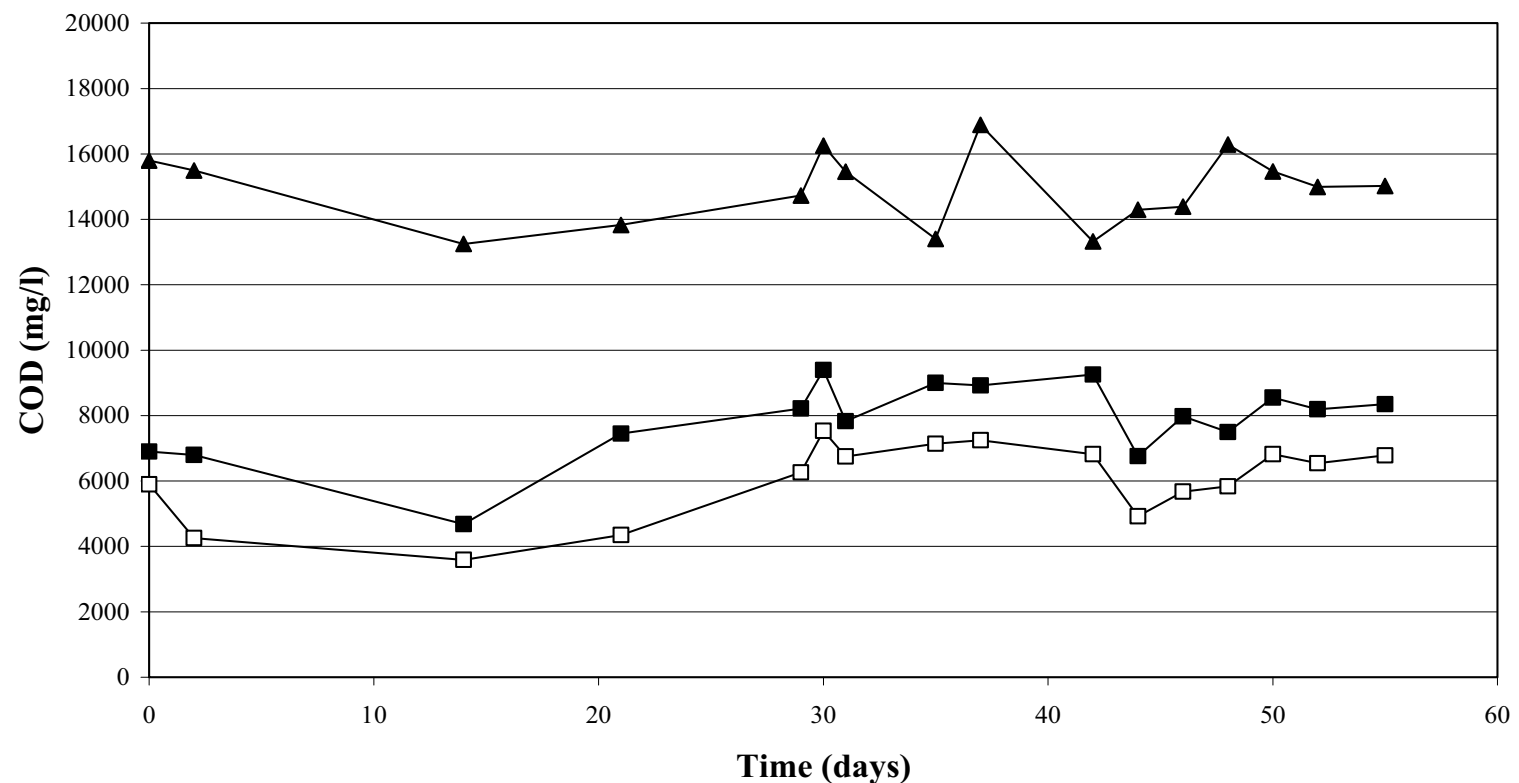

b

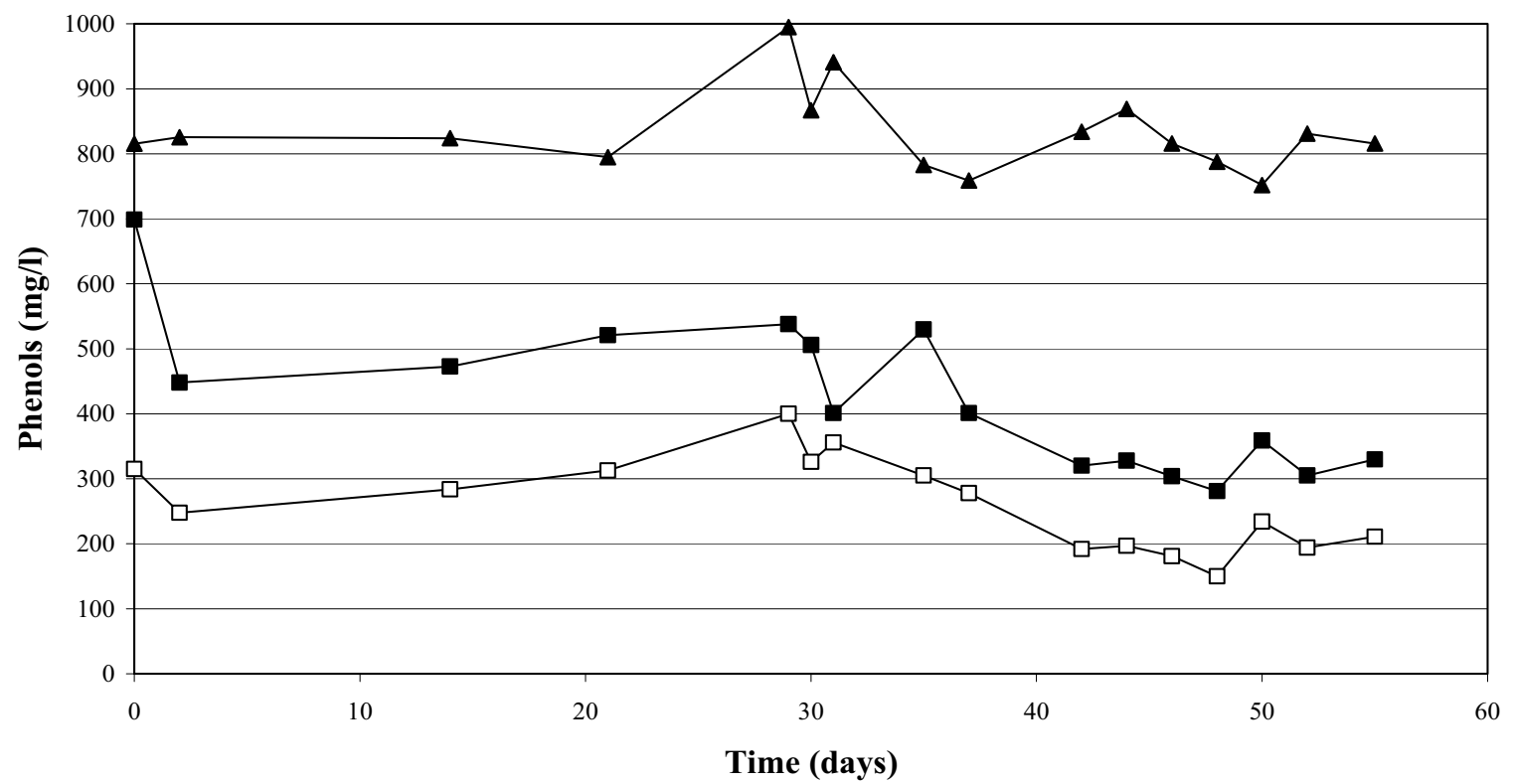

Figure 2

COD and phenol removals. Profiles of COD (a) and total phenol concentration (b) in the influent $(\mathbf{A})$ of the integrated anaerobic-aerobic process, in the influent $(\square)$ and the effluent $(\square)$ of the aerobic SB biofilter continuously fed with AOMW throughout the 56 days of treatment. Data provided were obtained through double measurements. 
ies already published on the biotreatment of OMWs [2$4,7,8,11-13,15]$, this is the first work in which the use of an integrated anaerobic-aerobic continuously operating biofilter system is proposed for such a purpose. Furthermore, this is also the first work in which an aerobic biofilter colonized by the native microflora of an anaerobically digested OMW is assessed under a technological and biological point of view.

\section{Results \\ Performances of the integrated anaerobic-aerobic biofilter system}

The integrated anaerobic-aerobic system was fed with AOMW at high and constant organic loading rate for a 2 month period (Table 1). Fig. 2 shows the evolution of COD and total phenol concentration in the influent of the integrated system and in the influent and the effluent of the aerobic biofilter throughout the whole experiment. The pollutant removal attained with the anaerobic digestion (expressed as COD or phenol removal efficiency, and calculated by dividing the amount of pollutant removed by the amount of pollutant occurring in the reactor influent) was of about 45 and $60 \%$ of initial AOMW COD and phenolic compounds, respectively. These removal efficiency were improved by about $30 \%$ through the aerobic post-treatment, thus permitting an overall removal of AOMW COD and phenol loading rates applied to the sequential anaerobic-aerobic treatment of about 59 and $76 \%$, respectively (Table 1). No HPLC-detectable aromatic metabolites accumulated in the aerobic SB-biofilter throughout the whole experiment. A large array of volatile fatty acids (acetate, propionic acid, iso-butyric acid, butyric acid and valeric acid) occurred in the SB-reactor influent, where they were responsible for about $30 \%$ of the influent COD, but they were not detected in the reactor effluent. $\mathrm{pH}$ and redox potential of the SB-reactor influent were $5.2 \pm 0.2$ and $-290 \mathrm{mV}$, respectively, but they increased markedly (up to 6.5 and $150 \mathrm{mV}$, respectively) as a result of the aerobic treatment.

\section{Biological features of the SB-biofilter}

The biological properties of the SB aerobic biofilter were investigated at the end of the 2 months of operation by determining its content of immobilized biomass and the structure and spatial distribution of its microbial community. The amount of immobilized biomass detected at 5, 20 and $38 \mathrm{~cm}$ of height (from the bottom) of the reactor packed-bed was (in mg of dried biomass/g of dried support) $12.74 \pm 0.85,11.38 \pm 1.01$ and $27.51 \pm 1.58$, respectively. Running the average of such values $(17.21 \mathrm{mg} / \mathrm{g}$ ) and considering that the reactor was packed with $0.213 \mathrm{~kg}$ of dried support, it can be estimated that the SB-reactor harbored a total immobilized biomass of $3.67 \mathrm{~g}$ (on dry weight basis).

The structure of the microbial community occurring at different regions of the reactor packed-bed as well as in the influent and effluent of the reactor, was investigated through T-RFLP analysis. Fluorescent amplifications of $16 \mathrm{~S}$ rRNA genes with universal eubacterial primers were successful for all of the samples examined. T-RFLP analysis of biofilm consortia obtained at 5,20 and $38 \mathrm{~cm}$ height of the reactor packed bed yielded the same three major TRFs of 81,280 and 392 bp length with RsaI restriction enzyme digestion. The three biofilm samples displayed similar T-RFLP patterns with a predominant T-RF with 81 bp of length (Fig. 3). Also the abundance of each bacterial population (represented as the peak height of each T-RF in relation to the total peak height of all T-RFs detected) was almost identical in the three biofilm samples. The major T-RFs detected in the influent after RsaI digestion were 98, 280 and 386 bp in length (Table 2). These peaks, which were detected and characterized in the effluent of the GAC reactor [8], were affiliated with Synergistes (clone B12, TRF of $98 \mathrm{bp}$ ), Bacteroides (clone B25, T-RF of $280 \mathrm{bp}$ ) and

Table I: COD and phenol removal efficiency. COD and total phenol loading rates with which the reactors were fed along with removal efficiency (\%) of COD and total phenol biodegradation occurred both in the sole reactors and in the whole integrated anaerobicaerobic system in steady state conditions.

\begin{tabular}{|c|c|c|c|c|c|c|c|c|c|c|}
\hline & $\begin{array}{l}\text { Experimen } \\
\mathrm{t} \text { duration }\end{array}$ & $\begin{array}{l}\text { Influent } \\
\text { COD }\end{array}$ & $\begin{array}{l}\text { Influent } \\
\text { Total } \\
\text { phenol } \\
\text { concentrat } \\
\text { ion } \\
\left(\mathrm{gl}^{-1}\right)\end{array}$ & $\begin{array}{c}\text { D } \\
\left(\text { day }^{-1}\right)\end{array}$ & $\begin{array}{l}\text { COD } \\
\text { Loading } \\
\text { rate }\end{array}$ & $\begin{array}{l}\text { Total } \\
\text { phenol } \\
\text { Loading } \\
\text { rate } \\
\left(\mathrm{gl}^{-1} \text { day }^{-1}\right)\end{array}$ & $\left(g l^{-1}\right)$ & $\begin{array}{c}\text { Effluent } \\
\text { Total } \\
\text { phenol } \\
\text { concentrat } \\
\text { ion } \\
\left(\mathrm{gl}^{-1}\right)\end{array}$ & $\begin{array}{c}\text { COD } \\
\text { Removal } \\
\text { efficiency } \\
(\%)\end{array}$ & $\begin{array}{c}\text { Total } \\
\text { phenol } \\
\text { Removal } \\
\text { efficiency } \\
(\%)\end{array}$ \\
\hline $\begin{array}{l}\text { GAC- } \\
\text { digestor }\end{array}$ & 55 & $\begin{array}{c}15.28 \pm \\
1.45\end{array}$ & $0.82 \pm 0.13$ & 2.077 & $\begin{array}{c}31.74 \pm \\
3.01\end{array}$ & $1.70 \pm 0.28$ & $8.35 \pm 0.75$ & $0.33 \pm 0.04$ & 45 & 60 \\
\hline $\begin{array}{l}\text { SB-aerobic } \\
\text { reactor }\end{array}$ & 55 & $8.17 \pm 0.77$ & $0.33 \pm 0.04$ & 6.171 & $\begin{array}{c}50.42 \pm \\
4.78\end{array}$ & $2.04 \pm 0.27$ & $6.24 \pm 0.69$ & $0.20 \pm 0.03$ & 24 & 39 \\
\hline $\begin{array}{l}\text { Integrated } \\
\text { System }\end{array}$ & 55 & $\begin{array}{c}15.28 \pm \\
1.45\end{array}$ & $0.82 \pm 0.13$ & & & & $6.24 \pm 0.69$ & $0.20 \pm 0.03$ & 59 & 76 \\
\hline
\end{tabular}


$\gamma$-Proteobacteria (clone B1, T-RF of 386 bp), respectively. Only T-RF of 386 bp in length was detected in the AOMW introduced in the integrated biofilters. A microbial community displaying T-RFLP patterns very similar to those obtained from biofilm was found to occur in the SB-reactor effluents (data not shown).

A total of 34 clones from 16S rRNA gene clonal libraries of biofilm consortia were randomly picked for PCR amplification and the amplified products digested with EcoRI, EcoRI plus KpnI and RsaI restriction enzymes. Eight different types of RFs (C81, C183, C280, C392, C610, H172, PS1 and PS156) were obtained (data not shown). Sequencing analysis of these RFs showed that clones from biofilm samples taken at different regions of the reactor having the same RF pattern were identical. The corresponding rDNA inserts were considered to belong to the same sequence type, resulting in the identification of 8 operational taxonomic units (OTUs). The sequences retrieved from the biofilm libraries were compared with the 16S rRNA reference sequences of the Ribosomal Database Project II database and were found to be $>80 \%$ identical to known rDNA sequences. Clone C280 was identical to clone B25 (Bacteroides group; Accession number AJ608923), which was detected in the effluent of the GAC reactor [8]. Clone C81 was closely related to Paracoccus versutus type strains ATCC 25364 (Accession number Y16962) and DSM 582 (Accession number Y16931) with 97.2\% similarity (Fig. 4 panel A) and to Paracoccus spp. strains isolated from a solid-phase denitrification process using poly( $\varepsilon$-caprolactone) as carbon and energy source
[16] with $97.6 \%$ similarity. The remaining six clonal sequences loosely related to Pseudomonadales (clone H172 with $80.7 \%$ similarity to Acinetobacter schindleri type strain LUH5832; clone PS1 with $80.7 \%$ similarity to Pseudomonas nitroreducens type strain LMG 1224; clone PS156 with 96.4\% similarity to Pseudomonas alcaliphila type strain AL15-21), Enterobacteriales (clone C392 with 75\% similarity to Enterobacter cloacae), Rhodocyclales (clone C610 with $94.0 \%$ similarity to Dechlorosoma spp. strain PCC) and genera incertae sedis TM7 (clone C183 with $89.5 \%$ similarity to uncultured bacterium TM7 LH21, Fig. 4 panel B). Analysis of clone distribution indicated that Paracoccus and Bacteroides were the major groups in the biofilm consortia obtained from the different portions of the reactor packed-bed (70\%, Fig. 5).

T-RFLP analysis of each RF showed that clone C81 could be matched with the 81 bp length fragment after RsaI digestion and clone $\mathrm{C} 280$ could be matched with the 280 bp length RsaI-fragment. In addition, clone C81 generated a small T-RF with the size of 385 bp after RsaI digestion due to incomplete digestion. Clone C183 generated a 183 bp length fragment which was a low abundant T-RF in the T-RFLP patterns of biofilm consortia. Clone C392 generated T-RF with the size of $392 \mathrm{bp}$, while clone H172 did not generate a RsaI T-RF.

\section{Discussion}

An intensified OMW anaerobic digesting process consisting of a GAC-packed bed biofilm reactor was recently developed and assessed [8]. In order to further reduce

Table 2: Results of T-RF analyses. Schematic representation of T-RFs obtained after Rsal digestion of I6S rRNA genes amplified from DNA of samples of OMW, anaerobically-treated OMW (GAC-reactor effluents) and biofilm from the SB-aerobic biofilter.

\begin{tabular}{|c|c|c|c|c|c|c|c|c|c|c|c|c|c|c|c|}
\hline \multirow[b]{2}{*}{$\begin{array}{l}\text { Samp } \\
\text { le }\end{array}$} & \multicolumn{15}{|c|}{ T-RF length (bp) } \\
\hline & 68 & 81 & 98 & 168 & 183 & 274 & 280 & 282 & 386 & 392 & 404 & 414 & 428 & 436 & 441 \\
\hline OMW & & & & & & & & & 94 & & & 4 & 2 & & \\
\hline $\begin{array}{l}\text { SB- } \\
\text { reacto } \\
r \\
\text { influen }\end{array}$ & & & 80 & 2 & & 1 & 7 & 3 & 4 & & 1 & & & 1 & 1 \\
\hline $\begin{array}{l}\mathrm{t} \\
\text { (GAC- } \\
\text { digest } \\
\text { or } \\
\text { effluen } \\
\text { t) }\end{array}$ & & & & & & & & & & & & & & & \\
\hline $\begin{array}{l}\text { SB- } \\
\text { reacto } \\
r \\
\text { biofilm }\end{array}$ & 2.6 & 37.7 & & & 1.7 & & 26.4 & & & 13.5 & & & 3.6 & 7.3 & 4.5 \\
\hline
\end{tabular}

The dominant (height) T-RF peak in each profile is indicated in boldface. Individual clones having a corresponding peak in the T-RF profiles are indicated below. The numbers indicate the relative abundance of individual T-RF. These values were calculated based on the peak height of individual T-RF in relation to the total peak height of all T-RFs detected in the respective community fingerprint pattern. The peak heights were automatically quantified by GeneScan software (PE Applied Biosystems), performing the analysis with a peak height threshold of 50 fluorescent units. 


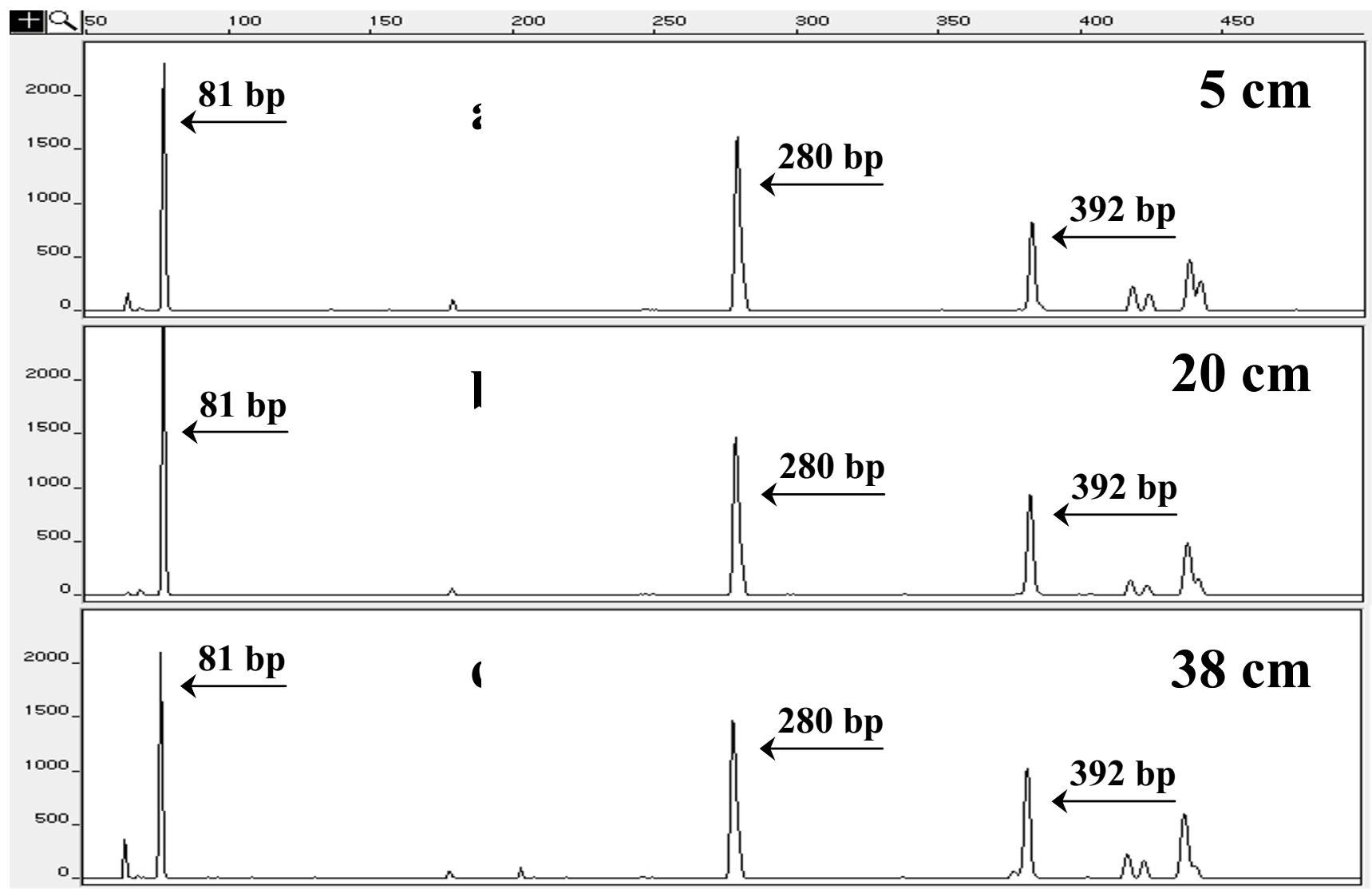

Figure 3

Biofilm electropherograms. Electropherogram of the 5' T-RFs derived from Rsal digestion of the Bacterial community I6S rDNA of the biofilm samples taken at different region of the reactor $(\mathrm{a}-5 \mathrm{~cm}, \mathrm{~b}-20 \mathrm{~cm}, \mathrm{c}-38 \mathrm{~cm}$ height).

COD of the effluents resulting from the process, the possibility of implementing the GAC-digestor with a tailored aerobic post-treatment was explored in this study. Integrated anaerobic-aerobic treatments have been often proposed for a high rate, cost effective and sustainable disposal of agroindustrial effluents [17-22]. However, a little is known $[13,23]$ about the feasibility of this approach in the management of OMWs. In the present study, a SB-packed bed biofilter was selected to post-treat digested OMW as the same technology was recently found to be very effective in the final decontamination of a similar anaerobically digested wastewater [23]. However, differently from this previous work, where it was inoculated with a defined co-culture of specialised bacteria and applied in discontinuous mode [23], SB-biofilm reactor was here hydraulically connected to the OMW digestor and allowed to be colonized by the influent native microflora able to grow on the SB surface under the aerobic conditions provided. To the very best of our knowledge, this is the first integrated anaerobic-aerobic biofilm system developed so far for an improved, continuous biomethanization and decontamination of OMWs.

The integrated biofilter system was assessed through a 2 month experiment performed under open mode of operation by feeding it with a high and constant AOMW organic loading rates. It was found to remove about 59 and $76 \%$ of COD and phenol loading rates, respectively. The aerobic post-treatment contributed for about $1 / 4$ of such removal efficiency, and these performances were comparable to those displayed on a similar anaerobically digested effluents by the aerobic conventional activated sludge post-treatment developed by Beccari et al. [13] and lower than those observed by Bertin et al. [8] with a similar aerobic SB-biofilm reactor. However, it has to be pointed out that the latter two processes were operated at lower COD and phenol loading rates and under batch mode.

SB-reactor biofilm was found to consist of Rhodobacterales, Bacteroidales, Pseudomonadales, Enterobacteriales, Rhodocy- 


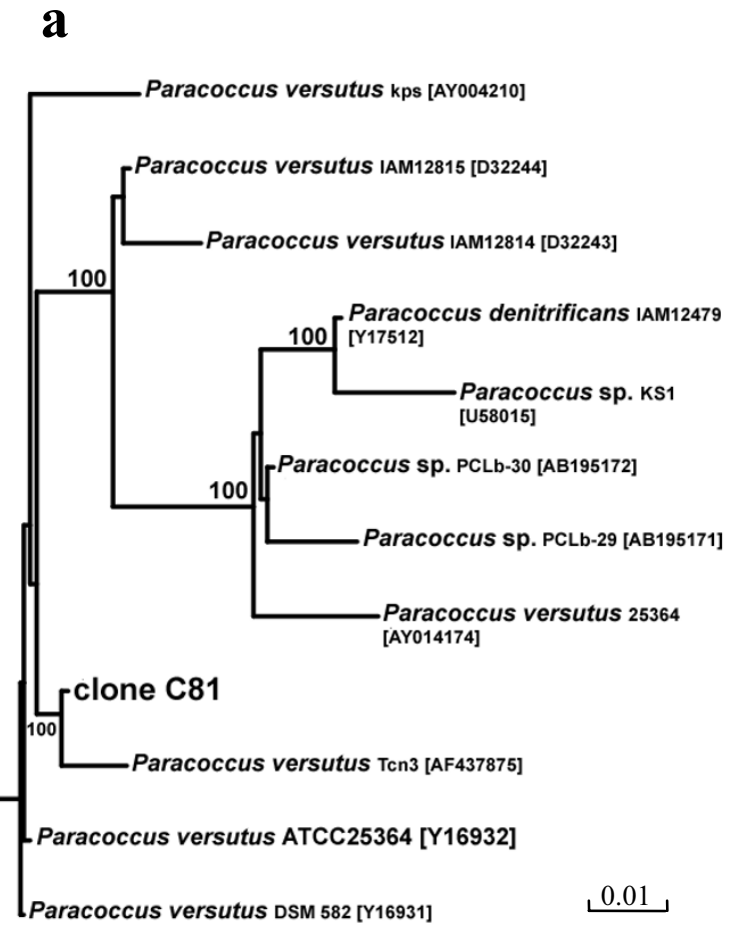

b

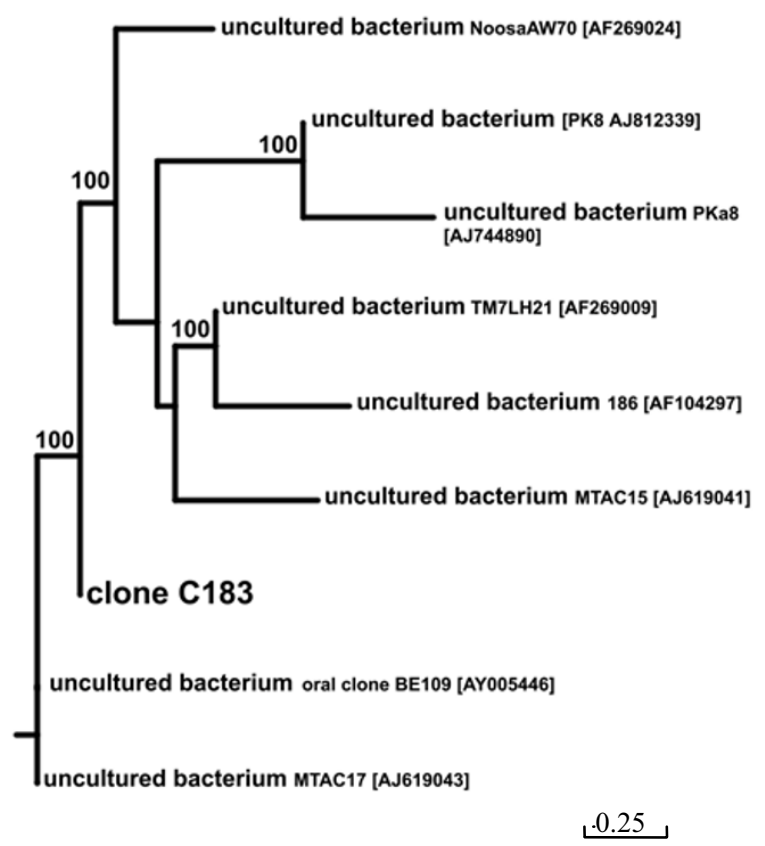

Figure 4

Phylogenetic trees of I6S rRNA genes. Phylogenetic trees of I6S rRNA genes belonging to Paracoccus (T-RF 81 bp; panel a) and genera incertae sedis TM7 (T-RF I 83 bp; panel b) analyzed using bootstrap and the neighbor-joining methods as distance measures. The cloned sequences are indicated in boldface and the GeneBank accession numbers of sequences are in bracket. The distance bar is shown under the tree, and bootstrap values (I000 replicates) are given for selected nodes.

clales and genera incertae sedis TM7. T-RFLP analysis and 16S rRNA gene cloning indicated that Paracoccus and uncultured strain B25 were the major groups occurring at different depths of the biofilter. Strain B25, an anaerobic bacterium of the Bacteroides group, was one of the major strains colonizing the GAC anaerobic digestor [8], whose effluents were used to feed the SB-aerobic biofilter. Instead, other members of the same group occurring in the anaerobic GAC biofilm digestor (i.e., uncultured bacteria B23 and B24) [8], were not found in the SB-biofilter. The presence of anaerobic Bacteroides in aerobic reactors has been already reported in the literature. The occurrence of these bacteria has been documented in conventional aerobic reactors treating municipal wastewaters [24] or anaerobically pre-treated tert-butyl alcohol-contaminated wastewaters [25], as well as in packed-bed biofilm reactors developed for the oxidization of sulfide-containing effluents [26]. Members of the Bacteroides group are often able to degrade various refractory biomacromolecules, such as cellulose, chitin, DNA, lipids, and proteins, which generally are abundant in a biofilm, in which dead microorganisms are trapped. These species are also known for their ability to produce exopolysaccharide slime, that generally has a primarily role in biofilm formation and development [27]. Thus, as suggested by Ferrera et al. [26], the presence of Bacteroides strains in aerobic biofilm reactors might be correlated to their role in the biofilm development and in the long-term functioning and versatility of the process. The abundant occurrence of the Paracoccus sp. $\mathrm{T}$-RF clone C81 in the biofilm is also interesting because Paracoccus is a quite biochemical versatile genus, able to display a wide range of degradative capabilities. Some Paracoccus strains are capable of aerobic denitrification (simultaneous reduction of oxygen and nitrate) and heterotrophic nitrification (oxidation of ammonium to nitrite during heterotrophic growth), whereas other strains are capable of a) aerobic growth on formate, b) aerobic chemolithoautotrophic growth using carbon disulfide as energy sources, c) methylotrophic growth on methanol or d) heterotrophic growth on diethyl sulfide, thioethanol, thioacetic acid or substituted thiophenes. Some other strains of this group can also grow anaerobically using thiosulfate, carbon disulfide, methanol or formate as energy sources and nitrate as final electron acceptor [28]. The classification of the genus Paracoccus (alpha subgroup of the Proteobacteria) has undergone seri- 

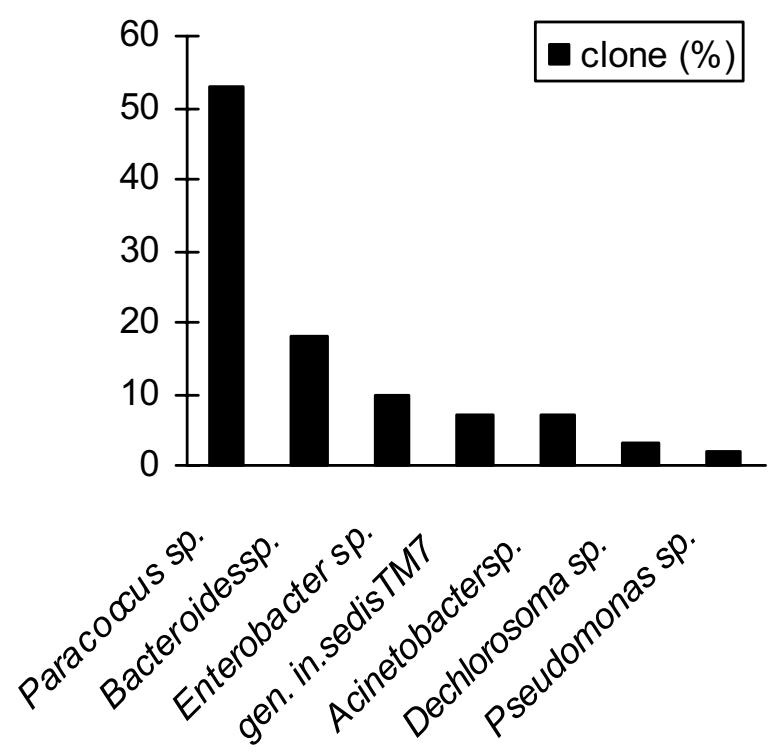

Figure 5

Clone distribution. Clone distribution based on the sequence of I6S rRNA genes recovered from clone libraries.

ous changes during the past decade [29]. Several new species have been isolated and, currently, the genus consists of 17 species, which can be found in different environments, including soil [30], contaminated groundwater [31], biofilters [32], sewage sludge [33], denitryfing reactors [34] and industrial wastewaters [35]. Bacteria belonging to the genus Paracoccus are important components of many wastewater treatment system communities [36]. Most species in the genus can use nitrate and its reduction products as an alternative electron acceptor to oxygen during anaerobic respiratory growth $[37,38]$, and, therefore, can survive and proliferate in ecosystems with fluctuating aerobic/anaerobic conditions. In our study, 16S rDNA sequences belonging to Paracoccus populations (T-RF 81 bp) were not detectable in the AOMW that entered the integrated process and in the SB-reactor influent. (Table 2 ). These bacteria were therefore massively enriched in the aerobic biofilm throughout the treatment to become the dominant eubacterial group. This finding might be ascribed to the ability of some Paracoccus species to denitrify in the presence of oxygen up to levels of $90 \%$ of air saturation $[39,40]$, ability that might allow the same strains to use both oxygen and nitrate as terminal electron acceptors [39] and therefore to have nutritional advantages that, in turn, might have allowed them to extensively colonize the reactor system developed in this study exposed to varying oxygen concentrations. The clonal analysis of the $16 \mathrm{~S}$ rRNA genes suggests that the microbial consortia that inhabit the aerobic biofilter also included minor members belonging to the uncultivated bacterial division TM7 (Fig. 4, panel B). Candidate division TM7 has no cultivated representatives and has been exclusively characterized by environmental sequence data. This division takes its name from the German peat bog from which the first sequence was obtained [41], but additional TM7 sequences deposited by several other investigators have demonstrated that members of this division are present in extremely diverse environments, including soil, freshwater, seawater, hot springs, mouse feces, termite guts, activated sludges and in human subgingival plaque samples [42-44]. In situ analysis revealed that members of the uncultivated TM7 division are capable of surviving and growing under a wide range of conditions. Ouverney et al. [45] suggested that TM7 members may be involved in the formation of a scaffold or biofilm, which could support the development of a disease-associated microbial community in human plaque. Thus, the evidence that TM7like 16S rDNA could be amplified from the samples taken at different regions of the reactor let to speculate that TM7related bacteria have had a role in the SB-biofilm formation. Unfortunately, the current limited knowledge on this uncultivated bacterial division does not allow us to speculate on the contribution that TM7 bacteria might have had on the aerobic decontamination of the anaerobic digested AOMW.

Other bacteria occurring in the biofilm consortia consisted of phylotypes affiliated with Pseudomonas, Acinetobacter and Enterobacter genera, which are common members of aerobic microbial consortia involved in the biodegradation of biogenic and xenobiotic compounds [46-48]. These members of Pseudomonadales and Enterobacteriales were not detected in the effluents of the anaerobic digestor and therefore enriched in the reactor throughout the 2 months-experiment. This suggests that they were significantly involved in removing organic compounds occurring in the anaerobically digested influent of the SB-aerobic reactor.

\section{Conclusion}

In conclusion, an effective aerobic biofilm technology able to significantly decontaminate anaerobically digested OMWs was developed, integrated with the anaerobic digestor and assessed in this study. To the very best of our knowledge, this is the first report in which a similar biofilm process is proposed for such a purpose and assessed through an integrated chemical and molecular biotechnology monitoring.

\section{Methods}

\section{Chemicals and OMWs employed}

Chemicals employed in the analysis of COD, total phenols as well as solvents used for HPLC and ion chromatography were obtained from Sigma-Aldrich (Milan, Italy) and Baker Italia (Milan, Italy). "Manville" silica spherical 
beads (diameter: $5 \mathrm{~mm}$ ) (SB) were supplied by Manville Filtration and Minerals (Denver, CO, USA).

An industrial OMW containing about $30 \mathrm{~g} / \mathrm{l}$ of COD and $2.0 \mathrm{~g} / \mathrm{l}$ of total phenols was collected from an Italian olive oil producing plant, stored in filled and sealed plastic jars at $4{ }^{\circ} \mathrm{C}$ and employed to prepare an amended OMW, AOMW, that was then used in the study. AOMW was prepared from the industrial OMW by a) diluting the latter with an equal volume of tap water, b) amending the obtained wastewater with $\mathrm{Ca}(\mathrm{OH})_{2}$ (up to have its $\mathrm{pH}$ equal to 6.5), urea $(0.45 \mathrm{~g} / \mathrm{l})$ and then $1 \mathrm{~N} \mathrm{NaOH}$ (to adjust its $\mathrm{pH}$ to $7.8 \pm 0.2$ ). AOMW was placed in $4 \mathrm{l}$ glass jars, where it was vigorously mixed (through a magnetic stirrer) and purged with $0.22 \mu \mathrm{m}$ filter (Millipore, $\mathrm{MO}$, USA)-sterilized $\mathrm{O}_{2}$-free $\mathrm{N}_{2}$ at room temperature for $3 \mathrm{~h}$, before being employed in the experiments. AOMW COD and total phenol concentration were about 15 and $0.8 \mathrm{~g} /$ l, respectively.

\section{Bioreactors, their inoculation, working conditions and sampling}

The bioreactor system employed in the study was composed by a GAC-packed bed anaerobic biofilm reactor hydraulically connected to an aerobic SB-packed bed biofilm reactor. AOMWs were continuously introduced in the first reactor and allowed to undergo sequential anaerobic biomethanisation and aerobic decontamination (Fig. 1).

Configuration, development procedure and working conditions of the GAC-anaerobic biofilter are reported in Bertin et al. [8], where this innovative bioreactor system has been described in detail. In brief, it was a $2.400 \mathrm{l}$, hermetically closed and thermostated glass column reactor equipped with a recycle line, an AOMW inlet line at the bottom and an outlet line (for treated wastewater and produced biogas) departing from the top and reaching a closed reservoir hydraulically connected to a $4 \mathrm{l}$ "Mariotte" bottle. After its packing with GAC (its working volume became 1.032 l) it was inoculated with the anaerobic, OMW-digesting microbial consortium developed by Beccari et al. $[12,13]$ and then employed under strictly anaerobic conditions for 9 months of experiments (see Bertin et al. [8] for more details). Biofilm occurring in the reactor at the end of the study was composed by Proteobacteria, bacteria of the Flexibacter-Cytophaga-Bacteroides group, sulfate-reducing bacteria, low $\mathrm{G}+\mathrm{C}$ gram-positive bacteria and, in a minor extent, Methanobacterium formicicum [8].

The aerobic reactor consisted of a $0.7 \mathrm{l}$ glass column reactor with an external jacket in which water at $30^{\circ} \mathrm{C}$ was continuously recycled (Fig. 1). The inlet line and the line for supplying $0.22 \mu \mathrm{m}$ filter-sterilized air were at the bottom of the column, whereas the outlet lines for exhaust air and treated wastewater were placed on a small reservoir located at the top of the reactor. A recycle line continuously carried wastewater from such a reservoir to the bottom of the reactor. In the same reservoir, a probe for dissolved oxygen (97-08 model, ATI-Orion, Boston, MA) and a probe for $\mathrm{pH}$ (81-04 model, ATI-Orion, Boston, MA) were also placed. The bioreactor system, sterilised by recycling an aqueous ethanol solution $(70 \% \mathrm{v} / \mathrm{v})$ containing $\mathrm{HCl}(1 \% \mathrm{v} / \mathrm{v})$ for 2 days, was washed with sterile water and then packed with $213 \mathrm{~g}$ (dry weight) of SB previously sterilised in autoclave $\left(110^{\circ} \mathrm{C}\right.$ per $\left.30 \mathrm{~min}\right)$. The developed reactor was made aerobic by supplying sterile air at $60 \mathrm{ml} /$ min and then fed with the effluent of anaerobic digestor. Considering the medium displacement due to the support $(0.330 \mathrm{l})$ and the supplied air $(0.020 \mathrm{l})$, the actual reactor working volume was $0.350 \mathrm{l}$. The reactor was allowed to operate in batch mode at high recycling flow rate (upflow; at $0.030 \mathrm{l} / \mathrm{min}$ ) for 2 weeks to permit a preliminary native biomass adhesion on SB surface. Then, it was forced to operate under continuous mode, and this by feeding it with the anaerobic digested wastewater at the same rate at which it was produced by the anaerobic digestor.

The sequential anaerobic-aerobic biofilter system was fed with AOMW at a high and constant organic load (calculated by multiplying COD or total phenol content of the influent by the dilution rate at which each reactor operated) for a 2-month period (Table 1). In particular, the anaerobic GAC-digestor was fed at a dilution rate $(\mathrm{D}$, expressed as the ratio between wastewater influent flow rate and the reactor reaction volume) of 2.077 day $^{-1}$ with COD and total phenol loading rates of about 31.74 and $1.70 \mathrm{gl}^{-1} \mathrm{day}^{-1}$, respectively. Given the AOMW decontamination efficiency achieved in the anaerobic digestor, such operative conditions imposed to the aerobic biofilter to operate at a D of 6.171 day $^{-1}$ and with COD and total phenol loading rates of 50.42 and $2.04 \mathrm{gl}^{-1} \mathrm{day}^{-1}$, respectively (Table 1). The recycle flow rate of each reactor was set up as a function of $\mathrm{D}$ to have a recycle ratio (defined as the ratio of the returned flow rate to the influent flow rate) of 77 for both reactors.

Six ml samples of wastewater were taken daily through sampling ports placed along the inlet line of the integrated reactor system, the inlet and outlet lines of the aerobic reactor (Fig. 1). The collected samples were filtered on $0.22 \mu \mathrm{m}$ cellulose-nitrate filters (Millipore, MO, USA) and then analysed for COD, the concentration of total phenols and that of volatile fatty acids as detailed in previous papers $[7,8]$. An aliquot of each sample was also analysed for low molecular weight phenols and aromatic compounds by HPLC [23]. At the end of the 2 monthexperiment, the aerobic reactor was opened and triplicate 3 g-samples of SB carrier were collected at 5, 20 and $38 \mathrm{~cm}$ of height (from the bottom) of the reactor packed-bed 
and subjected to gravimetric measurements of immobilized biomass. To this aim, the carriers were gently washed with distilled water, dried at $105^{\circ} \mathrm{C}$ for $16 \mathrm{~h}$, weighted and then suspended in a $1 \mathrm{M} \mathrm{NaOH}$ solution at $90^{\circ} \mathrm{C}$ for 20 min to induce the releasing of the attached biomass. Again, the biomass free carriers were washed with distilled water, dried at $105^{\circ} \mathrm{C}$ for $16 \mathrm{~h}$ and weighted. The biomass weight was calculated as the weight difference of the dried carrier before and after the $\mathrm{NaOH}$ treatment. A second set of SB samples (of about $20 \mathrm{~g}$ each) collected from the same regions of the reactor were washed and subjected to DNA extraction as described below.

\section{DNA extraction}

DNA was extracted from the biofilm, influent and effluent samples by using the DNeasy tissue kit (Qiagen, Italy) as described previously [8]. The amount and quality of nucleic acids were checked by electrophoresis on an ethidium bromide-stained $1 \%$ agarose gel.

\section{I6S rRNA amplification and T-RFLP analysis}

16S rRNA genes from the extracted DNA samples were amplified with universal eubacterial primers $63 \mathrm{~F}$ and 1389R [49]. The primer 63F was labeled with 6-FAM (5[6]-carboxy-fluorescein) on the 5'-end (Applied Biosystems, Italy). Fluorescently labeled PCR products (100 ng) were digested with $10 \mathrm{U}$ of restriction enzyme (Invitrogen, Italy) at $37^{\circ} \mathrm{C}$ for at least $4 \mathrm{~h}$. T-RFLP profiles were generated using the restriction enzyme RsaI. Additional profiles were generated using the restriction enzyme HhaI in order to confirm results obtained with RsaI, and to assist in the assignment of tentative phylogenetic affiliations to T-RFs. The digested samples were run on an ABI Prism 310 Genetic Analyzer (Applied Biosystems) operating in a GeneScan mode with filter set D and the sizes of fragments were compared with internal standards. Replicate T-RF profiles gave reproducible fingerprints.

\section{DNA sequencing and phylogenetic analysis}

Partial clone libraries of 16S rRNA genes were generated from community samples. Unlabeled PCR products, purified as described above, were cloned using the pGEM-T easy vector system (Promega) and Escherichia coli JM109 according to the manufacturer's instructions. From each library randomly selected clones were screened for positive inserts and by T-RF analysis using RsaI and HhaI restriction enzymes for digestion. Thirtyfour clones from the bacterial libraries were subjected to cycle sequencing using the M13 primers and the BigDye terminator cycle sequencing ready reaction kit (Applied Biosystems). The DNA sequences were bi-directionally resolved on an ABI Prism 310 in a sequencing mode. Nucleotide sequences were checked for potential chimeric sequences using the CHIMERA-CHECK software, and compared with the sequences in the Ribosomal Database Project (RDP) data- base to identify the closest relatives. The phylogenetic analysis was carried out according to the maximum likelihood method and neighbor-joining topology using the appropriate tools of the RDP program package. Bootstrapping using 1000 replicates was performed to test reliability of the branches of the trees.

\section{Competing interests}

The author(s) declare that they have no competing interests.

\section{Authors' contributions}

LB carried out the experimental work concerning the performances of the integrated anaerobic-aerobic biofilter system, MCC carried out the experimental work concerning the molecular characterization of biofilm developed in the aerobic post-treatment, MR coordinated the latter research activity as well as the manuscript preparation, LM coordinated the biotechnological process research activity and FF coordinated the biotechnological process research activity as well as the manuscript preparation. All authors read and approved the final manuscript.

\section{Acknowledgements}

The Authors thank Prof. M. Majone (Department of Chemistry, University of Rome "La Sapienza", Italy) for his suggestions and help, and the Frantoio Sant'Agata d'Oneglia (Imperia, Italy), for providing the OMW employed in the study. The project was funded by the Italian MIUR (COFIN/PRIN 2000), the Inter-University University Consortium "Chemistry for the Environment", Venezia, Italy and ISPESL, Italy (Project B96-2DIPIA/03).

\section{References}

I. Fiestas Ros de Ursinos JA, Borja-Padilla R: Biomethanization. Int Biodeter Biodeg 1996, 38: I45-153.

2. Rozzi A, Malpei F: Treatment and disposal of olive mill effluents. Int Biodeter Biodeg 1996, 38: |35-|44.

3. Hamdi M: Anaerobic digestion of olive mill wastewaters. Process Biochem 1996, 3 I: 105-I I0.

4. Rajeshwari KV, Balakrishnan M, Kansal A, Kusum Lata Kishore VVM: State of the art of anaerobic digestion technology for industrial wastewater treatment. Ren Sust Energy Rev 2000, 4: I35-I56.

5. Borja R, Alba J, Garrido SE, Martinez L, Garcia MP, Monteoliva M, Ramos-Cormenzana A: Effect of aerobic pretreatment with Aspergillus terreus on the anaerobic digestion of olive-mill wastewaters. Biotechnol Appl Biochem 1995, 22:233-246.

6. Beccari M, Majone M, Riccardi C, Savarese F, Torrisi L: Integrated treatment of olive oil mill effluents: effect of chemical and physical pretreatment on anaerobic treatability. Water Sci Technol 1999, 40:347-355.

7. Bertin L, Berselli S, Fava F, Petrangeli-Papini M, Marchetti L: Anaerobic digestion of olive mill wastewaters in biofilm reactors packed with granular activated carbon and "Manville" silica beds. Wat Res 2004, 38:3 I67-3 I78.

8. Bertin L, Colao MC, Ruzzi M, Fava F: Performances and microbial features of a granular activated carbon packed-bed biofilm reactor capable of an efficient anaerobic digestion of olive mill wastewaters. FEMS Microbiol Ecol 2004, 48:4I3-423.

9. Rozzi A, Passino R, Limoni M: Anaerobic treatment of olive mill effluents in polyurethane foam bed reactors. Process Biochem 1989, 26:68-74.

10. Morelli A, Rindone B, Andreoni V, Villa M, Sorlini C, Balice V: Fatty acids monitoring in the anaerobic depuration of olive oil mill wastewater. Biol Wastes 1990, 32:253-263.

II. Marques IP: Anaerobic digestion of olive mill wastewater for effluent re-use in irrigation. Desalination 2001, 137:233-239. 
12. Beccari M, Majone M, Petrangeli Papini M, Torrisi L: Enhancement of anaerobic treatability of olive oil mill effluents by addition of $\mathrm{Ca}(\mathrm{OH})_{2}$ and bentonite without intermediate solid/liquid separation. Proceedings of the Ist World Congress of the "International Water Association": 3-7 July 2000; Paris

13. Beccari M, Carucci G, Lanz M, Majone M, Petrangeli-Papini M: Removal of molecular weight fractions of COD and phenolic compounds in an integrated treatment of olive mill effluents. Biodegradation 2002, I3:40I-4I0.

14. Peredes C, Bernal MP, Roig A, Cegarra J: Effects of olive mill wastewater addition in composting of agroindustrial and urban wastes. Biodegradation 200 I, I 2:225-234.

15. Sayadi S, Allouche N, Jaoua M, Aloui F: Detrimental effects of polyphenols on olive mill wastewater biotreatment. Process Biochem 2000, 35:725-735.

16. Horiba Y, Khan ST, Hiraishi A: Characterization of the microbial community and culturable denitrifying bacteria in a solidphase denitrification process using poly( $\varepsilon$-caprolactone) as the carbon and energy source. Microb Environ 2005, 20:25-33.

17. Aggelis GG, Gavala HN, Lyberatos G: Combined and separate aerobic and anaerobic biotreatment of green olive debittering wastewater. J Agric Engng Res 2001, 80:283-292.

18. Uzal N, Gökçay CF, Demirer GN: Sequential (anaerobic/aerobic) biological treatment of malt whisky wastewater. Process Biochem 2003, 39:279-286.

19. Del Pozo R, Diez V: Organic matter removal in combined anaerobic-aerobic fixed-film bioreactors. Wat Res 2003, 37:3561-3568

20. Del Pozo R, Diez V: Integrated anaerobic-aerobic fixed-film reactor for slaughterhouse wastewater treatment. Wat Res 2005, 39: I I 14-1122

21. Gašpariková E, Kapusta Š, Bodík I, Derco J, Kratochvil K: Evaluation of anaerobic-aerobic wastewater treatment plant operations. Polish J Environ Studies 2005, I 4:29-34

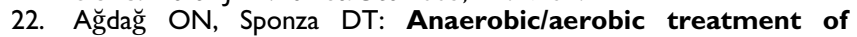
municipal landfill leachate in sequential two-stage up-flow anaerobic sludge blanket reactor (UASB)/completely stirred tank reactor (CSTR) systems. Process Biochem 2005, 40:895-902.

23. Bertin L, Majone M, Di Gioia D, Fava F: An aerobic fixed-phase biofilm reactor system for the degradation of the low-molecular weight aromatic compounds occurring in the effluents of anaerobic digestors treating olive mill wastewaters. J Biotechnol 2001, 87:161-177.

24. Tay ST, Ivanov V, Yi S, Zhuang WQ, Tay JH: Presence of anaerobic bacteroides in aerobically grown microbial granules. Microb Ecol 2002, 44:278-85.

25. Zhuang WQ, Tay JH, Yi S, Tay ST: Microbial adaptation to biodegradation of tert-butyl alcohol in a sequencing batch reactor. J Biotechnol 2005, I I 8:45-53.

26. Ferrera I, Massana R, Casamayor EO, Balagué V, Sánchez O, PedrósAlió C, Mas J: High-diversity biofilm for the oxidation of sulfide-containing effluents. Appl Microbiol Biotechnol 2004, 64:726-734

27. Kolenbrander PE, Andersen RN, Holdeman LV: Coaggregation of oral bacteroides species with other bacteria: central role in coaggregation bridges and competitions. Infection and Immunity 1985, 48:74|-746.

28. Baker SC, Ferguson SJ, Ludwig B, Page MD, Richter OM, van Spanning RJ: Molecular genetics of the genus Paracoccu s: metabolically versatile bacteria with bioenergetic flexibility. Microbiol Mol Biol Rev 1998, 62: 1046-78.

29. Rainey FA, Kelly DP, Stackenbrandt E, Burghardt J, Hiraishi A, Katayama Y, Wood AP: A re-evaluation of the taxonomy of Paracoccus denitrificans and a proposal for the combination Paracoccus pantotrophus comb. nov. Int J Syst Bacteriol 1999, 49:645-65I.

30. Beijerinck M, Minkman DC): Bildung undVerbrauch von Stickoxydul durch Bakterien. Zentralbl Bakteriol Parasitenkd Infektionsk 1910, 25:30-63.

3I. Doronina NV, Trotsenko YA, Krausowa VI, Suzina NE: Paracoccus methylutens sp. nov. - a new aerobic facultatively methylotrophic bacterium utilizing dichloromethane. Syst Appl Microbiol 1998, $21: 230-236$

32. Lipski A, Reichert K, Reuter B, Sproer C, Altendorf K: Identification of bacterial isolates from biofilters as Paracoccus alkenifer sp. nov. and Paracoccus solventivorans with emended description of Paracoccus solventivorans. Int J Syst Bacteriol I998, 48:529-536.

33. Vedenina IY, Govorukhina NI: Formation of a methylotrophic denitrifying coenosis in a sewage purification system for removal of nitrates. Mikrobiologiya 1988, 57:320-328.

34. Claus G, Kutzner HJ: Denitrification of nitrate and nitric acid with methanol as carbon source. Appl Microbiol Biotechnol I985, 22:378-38I

35. Ohara M, Katayama Y, Tsuzaki M, Nakamoto S, Kuraishi H: Paracoccus kocurii sp. nov., a tetramethylammonium-assimilating bacterium. Int J Syst Bacteriol 1990, 40:292-296.

36. Neef A, Zaglauer A, Meier H, Amann R, Lemmer $\mathrm{H}$, Schleifer $\mathrm{KH}$ : Population analysis in a denitrifying sand filter: conventional and in situ identification of Paracoccus spp. in methanol-fed biofilms. Appl Environ Microbiol 1996, 62:4329-4339.

37. Stouthamer $\mathrm{AH}$ : Metabolic regulation including anaerobic metabolism in Paracoccus denitrificans. J Bioenerg Biomembr 199|, 23:163-185.

38. Stouthamer AH, de Boer APN, van der Oost J, vanSpanning RJM: Emerging principles of inorganic nitrogen metabolism in Paracoccus denitrificans and related bacteria. Ant van Leeuwenhoek 1997, $71: 33-41$.

39. Robertson LA, Kuenen JG: Aerobic denitrification: a controversy revived. Arch Microbiol 1984, I 39:35I-354.

40. Davies KJP, Lloyd D, Boddy L: The effect of oxygen on denitrification in Paracoccus denitrificans and Pseudomonas aeruginosa. J Gen Microbiol 1989, I35:2445-245I

4I. Rheims H, Sproer C, Rainey FA, Stackebrandt E: Molecular biological evidence for the occurrence of uncultured members of the actinomycete line of descent in different environments and geographical locations. Microbiology 1996, I42:2863-2870.

42. Brand PAJ, Tiedt LR, Hamilton-Attwell VL: Some observations on the morphology and the anatomy of filament type 0041 . Water S Afr 1987, 13:1-6.

43. Hugenholtz P, Tyson GW, Webb RI, Wagner AM, Blackall LL: Investigation of candidate division $T M 7$, a recently recognized major lineage of the domain Bacteria with no known pureculture representatives. Appl Environ Microbiol 200 I, 67:4 I I-4I 9.

44. Paster BJ, Boches SK, Galvin JL, Ericson RE, Lau CN, Levanos VA, Sahasrabudhe A, Dewhirst FE: Bacterial diversity in human subgingival plaque. J Bacteriol 200 I, I 83:3770-3783.

45. Ouverney CC, Armitage GC, Relman DA: Single-cell enumeration of an uncultivated TM7 subgroup in the human subgingival crevice. Appl Environ Microbiol 2003, 69:6294-6298.

46. Saadoun I: Isolation and Characterization of Bacteria from Crude Petroleum Oil Contaminated Soil and their Potential to Degrade Diesel Fuel. Journal of Basic Microbiology 2002, 42:420-428.

47. Ghosh M, Verma SC, Mengoni A, Tripathi AK: Enrichment and identification of bacteria capable of reducing chemical oxygen demand of anaerobically treated molasses spent wash. J Appl Microbiol 2004, 96: I 278-86.

48. Robertson BK, Jjemba PK: Enhanced bioavailability of sorbed 2,4,6-trinitrotoluene (TNT) by a bacterial consortium. Chemosphere 2005, 58:263-70.

49. Osborn AM, Moore ERB, Timmis $\mathrm{KN}$ : An evaluation of terminalrestriction fragment length polymorphism (T-RFLP) analysis for the study of microbial community structure and dynamics. Environ Microbiol 2000, 2:39-50. 